their consultant colleagues. It might have been better to go the whole hog and ask that all those who teach in teaching hospitals should have the same status.

What the Todd Commission has to say about the reorganization of the teaching hospitals in London is almost certain to produce the most noticeable protests, if only because it will now be necessary to think of amalgamating institutions which have for years thrived on their jealous sense of independence. This has its roots in the doctrine of medical education by apprenticeship, and it is undeniable that the sense of individuality which the medical schools have enjoyed has given British medicine a good deal of its strength. But now that teaching needs roots in the laboratories, the medical schools are plainly hopelessly too small and too fragmented. Most probably the proposal that the twelve colleges in London should be amalgam. ated into six is that best calculated to win acceptance, but here, again, there is at least a possibility that a still more radical solution might have been preferable. Is it, for example, entirely beyond the bounds of good sense that all twelve medical schools in London should be amalgamated into one? Those who shrink from the ructions that lie ahead will naturally shrink from that suggestion and if what matters is to get things done, and they are probably right. That is the hallmark of the Todd Report-it is enlightened but practical. The sooner its proposals are adopted, however, the sooner another Royal Commission will be necessary.

\section{British Computer Boom}

DeLIVERIES of computers by firms in Britain were a record in 1967-an optimistic omen for the newly formed International Computers, Ltd. Computers and associated equipment made in the United. Kingdom and delivered last year were worth $£ 96 \cdot 1$ million, an increase of 23 per cent on the 1966 figure. The home market absorbed $£ 60.5$ million of this, an increase of 30 per cent on the previous year, and $£ 35 \cdot 6$ million was exported, up by 12 per cent on 1966 . On the other hand, deliveries of factored machinesmachines sold by firms other than the manufacturerfell by 15 per cent to $£ 31 \cdot 1$ million. Most of the factored equipment was imported material for the home market.

These statistics are from a Ministry of Technology survey of the computer market in the United Kingdom,

Table 1. DELIVERIES OF BRITISH-MADE DIGITAL COMPUTING SYSTEMS AND INDUSTRIAL ELECTRONIC CONTROL EQUIPMENT

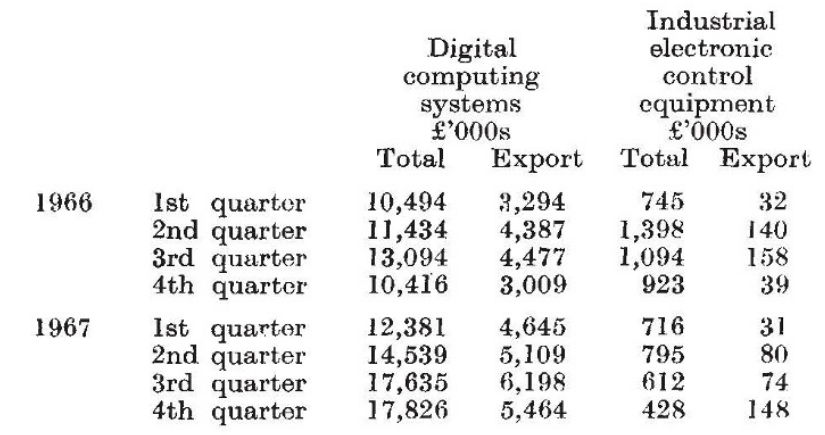

and are based on enquiries to the computer industry. The figures issued by the ministry include a breakdown showing how the total deliveries were made up of digital computing systems, analogue and hybrid computers, data transmission equipment, industrial electronic control equipment, and peripheral equipment. The figures are available for each quarter in 1966 and 1967, and according to the ministry include rentals.

At first sight, the statistics provide a useful survey of the state of the British computer industry. The manufacturers are not so impressed, however. They point out that without definitions of exactly what the ministry understands by the several classes into which Britain's computer output is divided the figures are meaningless.

The decision to publish quarterly statistics for the delivery, import and export of computers reflects the growing tendency to judge a nation's standing in technology by the extent it is using computers. There are dangers in this, of course. As Dr Jeremy Bray, Joint Parliamentary Secretary, Ministry of Technology, pointed out in January, the figures vary greatly from quarter to quarter because of the nature of the industry, and therefore cannot be taken as indicating a trend.

Nevertheless the figures are published and at first sight look encouraging. The difficulty is to know to what extent the introduction of highly expensive digital computing systems, which scem to be largely responsible for the increase in deliveries last year, gives a true indication of technological progress. The table shows their contribution to computer sales for the period when statistics are available. These large off-line machines are chiefly for accountancy and documentation applications, and are not directly concerned with the improvement of manufacturing processes. More important is the increasing use of computers for the scheduling of production on the shop floor and the control of stock. Although systems for this kind of work are cheaper than the large machines used in accountancy, their economic worth may prove to be just as great. For this reason the drop in deliveries of industrial electronic control equipment to the home market, revealed by the ministry's survey, is ominous.

\section{Foot and Mouth in Europe}

At the fifteenth session of the European Commission on the Control of Foot and Mouth Disease of the FAO, held in Rome from March 26-28, a Russian observer allayed the fears of representatives from elsewhere in Europe that the strain of foot and mouth virus now active in the Soviet Union (A22) would spread. Dr M. A. Khoudiakov insisted that in 1967, there were only sporadic outbreaks of the disease, and that they were being contained by a combination of slaughter. vaccination and quarantine.

The commission, which consists of veterinarians from the seventeen member nations which contribute to its meagre budget, was set up in 1963-64 to organize the control of foot and mouth disease in Europe. The Soviet Union, together with the other countries of Eastern Europe and France, Germany and Spain, is not a member and has not previously sent an observer to the meetings. But the epizootic in Britain and the publicity given in December to outbreaks of $A 22$ in the Soviet Union following the visit of Dr G. M. Bol- 